\title{
Ruang Lingkup dan Aspek-aspek Kebijakan Pembaharuan Hukum Acara Perdata di Indonesia
}

\section{Bambang Sutiyoso}

\begin{abstract}
This written is aimed to give constribution and suggestion in the frame for law of civil reform in Indonesia. As we know that the civil law procedure which is existing today is apprehensive enough. Although the freedom of Republic of Indonesia have been proclaimed more than 50 years in the last time, tumed out Indonesia still apply law of civil procedure made by Dutch Government that was relativel out of date so that it has, no social relevance with social situation and condition governed. The law of civil procedure reform, therefore in Indonesia is as conditio sine qua non in the effort of producing the law exactness and the justice. The law of civil procedure existing today need to be rediscussed and reformed by the new law of civil procedure that is visioner and responsive, either philosophic, jurisdic or sociologic views.
\end{abstract}

\section{Pendahuluan}

Eksistensi hukum acara perdata sebagai hukum formil, mempunyai kedudukan penting dan strategis dalam upaya menegakkan hukum perdata (materiel) di. lembaga peradilań. Sebagai hukum formil, hukum acara perdata berfungsi untuk menegakkan, mempertahankan dan menjamin ditaatinya hukum perdata (materiel) di dalam praktek pengadilań. Oleh karena itu, hukum perdata eksistensinya terkait èrat dengản hukum acara perdata, bahkan ,keduanya merupakan pasangan satu sama lain yang tidak dapat dipisahkan. Hukum perdata tidak mungkin dapat berdiri sendiri lepas dari hukum acara perdata, sebaliknya hukurri acara perdata juga tidak mungkin berdiri sendiri tanpa adanya hukum perdata.' Menurut Sjahran Basah, hukum açara merupakan salah satu unsur dari peradilan, demikian pula dengan hukum materielnya. Peradilan tanpa hukum material akan lumpuh, sebab tidak tahu apa yang akan dijelmakkan, sebaliknya peradilan tanpa húkum formal akan liar, sebab tidak ada batas-batas yang jelas dălam melakukan wewenangnya. ${ }^{2}$

'Sudikno Mertokusumo. 1998. Hukum Acara Perdata Indoñesia. Yogyakärta: Liberty. Him: 5.

2Sjachran Basah. 1989. Hukum Acara Pengadilan Dalam Lingkungan Peradilan Administrasi (HAPLA). Jakarta: Rajawali Pers. Hlm. 1. Lihat pula bukunya Zairin Harahap. 2001. Hukum Acara Peradilan Tata Usaha Negara. Jakarta: RajaGrafindo Perșada. HIm. 24. 
Meskipun demikian, peraturan hukum acara perdata yang ada sekarang ini cukup memprihatinkan. Kendati kemerdekaan Republik Indonesia telah diproklamirkan lebih dari 50 tahun yang lalu, ternyata sampai saat ini Indonesia masih menggunakan hukum acara perdata produk dari peninggalan pemerintah Hindia Belanda, yaitu $\mathrm{HIR}^{3}$ dan RBG. ${ }^{4}$ Karena konsep dan desainnya dibuat oleh bangsa penjajah, baik HIR maupun RBG secara filosofis jelas tidak didasarkan pada jiwa dan pandangan hidup bangsa Indonesia. Apalagi mengingat usianya yang sudah lebih dari seabad, tentunya secara materi ketentuan hukum acara perdata yang ada sekarang ini relatif sudah usang dan sulit mengikuti berbagai perkembangan hukum, terutama dengan bermunculannya berbagai lembagalembaga baru dalam hụkum sekarang ini. Sebagai contoh dalam praktek peradilan perdata mulai marak digunakannya gugatan secara class action (perwakilan kelompok), munculnya alat bukti baru dalam sistem transaksi bisnis elektronik, seperti penggunaan sistem elektronic record (catatan elektronik) dan digital signature (tanda tangan digital), yang secara prosedural belum ada aturannya.

Dibandingkan dengan hukum formil lainnya, legislasi hukum acara perdata jelas jauh tertinggal dan terlambat. Hukum acara perdata yang sudah berumur ratusan tahun itu hingga kini masih tetap dipertahankan dan mungkin sebagai satu-satunya hukum formil yang belum diatur dalam perundangundangan yang baru, produk hukum nasional setelah Indonesia merdeka. Oleh karena itu, tidak mengherankan apabila peraturan hukum acara perdata sampai sekarang ini belum ada unifikasi, tetapi sebaliknya peraturannya masih bersifat pluralistis, yaitu tersebar dalam berbagai peraturan perundang-undangan yang $a d a .^{5}$

${ }^{3}$ HIR singkatan dari Het Herzeine Indonesisch Reglement atau Reglemen Indonesia yang diperbaharui (RIB). HIR adalah hukum acara perdata yang berlaku bagi wilayah di Jawa dan Madura. HIR sebenarnya berasal dari IR (Inlandsch Reglement atau Reglemen Bumiputera), hasil rancangan dari JHR. Mr. HL. Wichers, President Hooggerechhtshof (Ketua Pengadilan Tertinggi di Indonesia pada zaman Hindia Belanda yang berkedudukan di Batavia). Pertama kali diundangkan tanggal 5 April 1848 yang dimuat dalam Stb. 1848 No. 16. Ketentuan hukum acara perdata dituangkan dalam Pasal 115 sampai dengan 245 serta beberapa Pasal yang tersebar antara Pasal 372 sampai dengan 394 HIR, sebab rangkaian Pasal-pasal yang terakhir ini mengatur hal-hal yang, berkaitan dengan hukum acara perdata dan hukum acara pidana.

${ }^{4}$ RBG singkatan dari Recht Reglement.voor de Buttengewesten atau reglemen untuk daerah seberang. RBG adalah hukum acara perdata yang berlaku untuk wilayah di luar Jawa dan Madura. Pertama kali diündangkan tanggal 11 Mei 1927 dan dimuat dalam Stb. 1927 №. 227. Ketentuan hukum acara perdata dimuat dalam Bab ke-2, mulai dari Pasal 104 sampai dengan $323 \mathrm{RBg}$.

${ }^{5} \mathrm{Peraturan}$ hukum formil lainnya sudah diatur dengan perraturan perundang-undangan sendiri, sebagai produk hukum nasional setelah Indonesia merdeka. Seperti diketahui, hukum acara pidana sudah diatur dengan UU No. 8 Tahun 1981 tentang Kitab Undang-Undang Hukum Acara Pidana (KUHAP), hukum acara PTUN sudah diatur dengan UU No. 5 Tahun 1986, hukum acara Peradilan Agama diatur dengan UU No. 7 Tahun 1989 dan hukum acara Peradilan Militer diatur dengan UU No. 31 Tahun 1997, dan terakhir dikeluarkannya UU No. 26 Tahun 2000 tentang Peradilan HAM. Sedangkan UU No. 2 Tahun 1986 tentang Peradilan Umum tidak secara spesifik mengatur tentang hukum acara perdata. 
Sesuai dengan perkembangan hukum dewasa ini, kehadiran peraturan hukum acara perdata yang visioner dan responsif, yang dapat mengantisipasi dinamika perkembangan hukum masyarakat, merupakan conditio sine qua non. Terlebih lagi, pengajuan tuntutan hak, khususnya gugatan dalam bidang hukum perdata dari masyarakat ke pengadilan, semakin hari semakin menunjukkan peningkatan yang cukup signifikan. Tingginya tuntutan hak keperdataan dari masyarakat yang diajukan ke pengadilan, tentu memerlukan penanganan dan penyelesaian yang profesional. Hal tersebut perlu didukung dengan perangkat instrumen hukum yang memadai, dalam hal ini tersedianya hukum acara perdata, sebagai pedoman dan aturan main (rule of game) bagi hakim dalam memeriksa, mengadili dan memutuskan perkara perdata.

Keadaan ini menunjukkan bahwa law reform (pembaharuan hukum) dalam bidang acara perdata dewasa ini sangatlah urgen dan relevan untuk dilakukan, dan tidak dapat ditunda-tunda lagi. Pembaharuan hukum acara perdata merupakan upaya untuk mengganti tatanan hukum acara perdata positif (Ius Constitutum) yang tidak sesuai dengan perubahan sosial dan aspirasi masyarakat dengan tatanan -hukum acara perdata yang dicita-citakan (lus Constituendum) yang sejalan dengan kebutuhan masyarakat dan tuntutan perkembangan zaman. Pembaharuan tatanan hukum acara perdata positif perlu segera dilaksanakan oleh badan legislatif. ${ }^{6}$ Dengan kehadiran hukum acara perdata baru, yang bernuansakan spirit pembaharuan, diharapkan dapat ikut membantu mewujudkan adanya kepastian hukum dan rasa keadilan masyarakat.

\section{Tujuan dan Sifat Hukum Acara Perdata}

Seperti diketahui, adanya ketentuan hukum perdata (máteriil) saja ternyata belum sepenuhnya dapat memberikan jaminan dan perlindungan t terhadap kepentingan masyarakat. Betapapun baiknya hukum perdata (materiil), kalau hak-hak dan kewajiban yang ditentukan di dalamnya tidak dapat dilaksanakan, maka hukum perdata (materiil) tidak akan berakibat apa-apa. Dalam kehidupan bermasyarakat, seringkali dijumpai adanya pelanggaran terhadap norma-norma atau kaidah hukum perdata, yang menimbulkan suatu kerugian terhadap pihak lain. Pelanggaran terhadap hukum perdata akan menimbulkan perkara perdata, yaitu perkara dalam ruang lingkup hukum perdata. Dalam suatu negara hukum, upaya penyelesaian perkara perdata tidak diperbolehkan dengan cara menghakimi sendiri (eigenrichting/own arbitrarily action), tetapi harus dengan cara-cara yang sudah diatur dalam hukum acara perdata atau caracara lain yang tidak bertentangan dengan perundang-undangan. Seluk beluk bagaimana caranya menyelesaikan perkara perdata melalui lembaga peradilan diatur dalam hukum acara perdata.

${ }^{6}$ Bandingkan dengan Salman Luthan. "Kebijakan Kriminalisasi dalam Reformasi Hukum Pidana." Jurnal Hukum No.11 Volume 6.1999. HIm.1. 
Dengan adanya hukum acara perdata, masyarakat merasa ada kepastian hukum bahwa setiap orang dapat mempertahankan hak perdatanya dengan sebaik-baiknya, dan setiap orang yang melakukan pelanggaran terhadap hukum perdata yang mengakibatkan kerugian terhadap orang lain dapat dituntut melalui pengadilan. Dengan hukum acara perdata diharapkan tercipta ketertiban dan kepastian hukum dalam masyarakat.?

Untuk dapat mencapai tujuan dari hukum acara perdata seperti di atas, maka pada umumnya peraturan-peraturan hukum acara perdata bersifat mamaksa ( $d$ wingend recht), karena dianggap menyelenggarakan kepentingan umum. Peraturan hukum acara perdata yang bersifat memaksa tidak dapat dikesampingkan oleh pihak-pihak yang berkepentingan dan pihak-pihak tersebut mau tidak mau harus tunduk dan mematuhinya. Apabila ketentuan hukum acara perdata sampai dilanggar, akan mengakibatkan ruginya pihak-pihak itu sendiri atau apabila ketentuan itu tidak dipatuhi oleh hakim, dapat berakibat putusannya tidak sah menurut hukum. Sebagai contoh, pada asasnya seorang penggugat harus mengajukan gugatan di Pengadilan Negeri di mana tergugat tinggal (actor sequitor forum rei). Oleh karena itu, apabila gugatan diajukan di tempat lain, akan berakibat gugatan tidak diterima (Niet Onvankelijke Verklaard), karena bukan merupakan kompetensi dari pengadilan yang bersangkutan. Demikian pula; apabila hakim tidak membuka persidangan untuk umum, maka dapat berakibat putusan yang dijatuhkan tidak sah menurut hukum atau batal demi hukum (Pasal 17 UU No. 14 Tahun 1970):

Meskipun demikian ada juga bagian dari peraturan hukum acara perdata yang bersifat pelengkap (aanvullend recht), karena dianggap mengatur penyelenggaraan kepentingan khusus dari yang bersangkutan, sehingga dapat dikesampingkan atau disimpangi oleh pihak-pihak yang berkepentingan. Misalnya dalam hal penggunaan alat-alat bukti di persidangan, pihak-pihak yang berperkara dapat mengadakan perjanjian yang menetapkan bagi mereka hanya dapat mempergunakan satu macam alat bukti saja, umpamanya tulisan, dan pembuktian dengan alat bukti lain tidak diperkenankan. Perjanjian yang mengatur tentang pembuktian yang berlaku bagi orang-orang yang mengadakan perjanjian tersebut dinamakan "perjanjian pembuktian", yang menurut hukum memang diperkenankan dalam batas-batas tertentu. ${ }^{9}$

Dalam rangka melaksanakan ketentuan hukum acara perdata di pengadilan, dikenal ada tiga tahap tindakan dalam beracara, yaitu tahap pendahuluan (persiapan), penentuan, dan tahap pelaksanaan. ${ }^{10}$ Tahap pendahuluan adalah tahap untuk

'Riduan Syahrani. 2000. Buku Materi Dasar hukum Acara Perdata. Bandung: Citra Aditya Bakti. HIm. 3. 8 Ibid.

9Subekti. 1975. Hukum Pembuktian. Jakarta: Pradnya Paramita. HIm. 63.

${ }^{10}$ Sudikno Mertokusumo. Op. Cit. HIm. 6. Lihat pula bukunya Abdul Kadir Muhammad. 1992. Hukum Acara Perdata Indonesia. Bandung: Citra Aditya Bakti. Hlm. 20-21. Rubini dan Chidir Ali. 1974. Pengantar Hukum Acara Perdata. Bandung: Alumni. Hlm. 9. 
mempersiapkan segala sesuatu guna sidang pemeriksaan perkara dan mempersiapkan pelaksanaan putusan. Termasuk dalam tahap ini antara lain " pencatatan perkara dalam daftar, penetapan versekot biaya perkara dan berita acara secara prodeo, penetapan hari sidang, panggilan terhadap pihak-pihak yang berperkara, dan pengajuan sita jaminan (conservatoir beslag). Tahap penentuan merupakan tahap mengenai jalannya proses perkara di pengadilan, mulai dari tahap pemeriksaan peristiwa, pembuktian sampai pada putusannya. Tahap terakhir, yaitu tahap pelaksanaan merupakan tahap untuk merealisir putusan hakim yang sudah berkekuatan hukum tetap (in kracht van gewijsde). Dengan demikian, secara umum dalam beracara perdata, mulai dari pengajuan gugatan, pemeriksaan perkara sampai pada pelaksanaan putusannya mengikuti tahap-tahap tersebut, kecuali dalam hal-hal lain seperti dijatuhkannya putusan perdamaian, putusan gugur, putusan verstek, dan sebagainya.

\section{Ruang lingkup Pembaharuan Hukum Acara Perdata}

Sebenarnya upaya untuk memperbaharui dan mengganti peraturan Hukum Acara Perdata yang bersifat nasional telah sejak lama dilakukan.' Bahkan beberapa konsep Rancangan Undang-Undang (RUU) Hukum Acara Perdata sudah berhasil dirumuskan oleh tim penyusun. Di antaranya adalah RUU Tahun 1984, RUU Tahun 1991, RUU Tahun 1994/1995 dan konsep terakhir adalah RUU hasil pembahasan Tim Antar Departemen dan Direktorat Perundang-undangan Departemen Kehakiman Republik Indonesia Tahun 1995/ 1996. Meskipun demikian dalam perjalanannya agak tersendat-sendat hingga saat ini, karena konsep-konsep RUU tersebut selalu mandeg di tengah jalan sebelum sampai masuk dalam-pembahasan di lingkungan Dewan Perwakilan Rakyat (DPR). Tentunya yang diharapkan adalah adanya political will dari pemerintah untuk segera melakukan langkah-langkah kongkrit, untuk mempercepat lahirnya hukum acara perdata yang baru yang sudah lama dinantikan.

Adapun ruang lingkup pembaharuan hukum acara perdata yang harus diperhatikan setidak-tidaknya meliputi tiga hal yang bersifat mendasar, yaitu pembaharuan muatan filosofis, yuridis (normatif), dan sosiologis. Pembaharuan muatan filosofis dimaksudkan untuk mengkaji ulang relevansi konsep dasar dan asas-asas hukum acara perdata, pembaharuan muatan yuridis (normatif) dimaksudkan untuk mengevaluasi muatan dari norma-norma atau kaidah hukum positif yang berlaku sekarang ini, sedangkan pembaharuan muatan sosiologis dimaksudkan agar lahirnya suatu peraturan perundang-undangan baru tidak mendapat tantangan dari masyarakat, oleh karena itu sedapat mungkin aspirasi dari masyarakat dapat terwadahi dengan baik.

\section{Pembaharuan Filosofis}

Keberlakuan suatu peraturan hukum, perlu ditelaah lebih jauh kesesuaiannya dengan

1'Subekti. 1989. Hukum Acara Perdata. BPHN Departemen Kehakiman. Bandung: Bina Cipta. HIm. 36. 
alam pikiran hukum dan falsafah hidup bangsa indonesia. Adapun tolok ukur praktis mengenai filsafat hukum nasional tidak lain adalah Pancasila. Pancasila sebagai ideologi negara menempatkan. kelima sila yang ada merupakan prinsip dasar serta pedoman dalam kehidupan bermasyarakat, berbangsa dan bernegara.

Sehubungan dengan itu, pembaharuan hukum acara perdata memerlukan adanya rumusan-rumusan asas hukum acara perdata yang sesuai dengan falsafah hidup bangsa indonesia. Dengan adanya asas-asas hukum acara perdata nasional tersebut, maka setiap adanya perubahan hukum harus berorientasi kepada asas-asas tersebut. Sehingga mampu tercipta hukum yang mampu mengayomi masyarakat tanpa diskriminasi, hukum yang melindungi masyarakat dari kesewenangwenangan kekuasaan, hukum yang berdimensi keadilan, hukum yang responsif terhadap berbagai fenomena perubahan serta konflik-konflik yang ada dalam realita kehidupan masyarakat.12

Sebagaimana hukum lain, hukum acara perdata juga mempunyai beberapa asas yang dijadikan acuan dalam proses beracara di pengadilan. Hukum acara perdata yang baru perlu memperhatikan adanya asas-asas umum peradilan (perdata) yang baik (Algemene beginselen van behoorlijk rechtspraak). Beberapa asas yang perlu mendapat perhatian sehubungan dengan pembaharuan hukum acara perdata di masa mendatang, akan dikemukakan di bawah ini.

\section{Asas kebebasan hakim}

Asas kebebasan hakim merupakan asas yang bersifat universal, yang berlaku di semua negara hukum. Asas ini, berarti bahwa dalam melaksanakan peradilan, hakim itu harus bebas, yaitu bebas dalam memeriksa dan mengadili perkara dan bebas dari campur tangan atau turun tangan kekuasaan ekstra yudisial lainnya. Dalam hukum acara perdata yang baru, asas ini perlu diatur secara jelas dengan diisertai adanya jaminan dan sanksi yang tegas.

\section{Asas Hakim bersikap Menunggu}

Asas ini berarti bahwa inisiatif berperkara di pengadilan ada pada pihak-pihak yang berkepentingan, sedangkan hakim bersikap menunggu datangnya tuntutan hak yang diajukan kepadanya (iudex ne procedat ex officio). Jadi akan ada proses atau tidak, ada tuntutan hak atau tidak diserahkan sepenuhnya kepada pihak-pihak yang berkepentingan. ${ }^{13}$ Asas ini kiranya dapat dipahami, karena hukum acara perdata mengatur bagaimana para pihak mempertahankan kepentingán pribadinya. Berbeda dengan hukum acara pidana yang mengatur cara-cara mempertahankan kepentingan publik, maka inisiatif berperkara dilakukan oleh pemerintah yang diwakili oleh Jaksa Penuntut Umum atau alat-alat perlengkapan negara lainnya (kepolisian). ${ }^{14}$

12Bandingkan dengan Artidjo Alkostar. "Reformasi Hukum Pidana Politik." Jurnal Hukum No. 11 Volume 6. Tahun 1999.

${ }^{13}$ Sudikno Mertokusumo. Op.Cit. HIm. 10.

${ }^{14}$ Riduan Syahrani. Op. Cit. HIm. 16. 


\section{Asas hakim aktif}

Hakim selaku pimpinan sidang harus aktif baik sebelum maupun selama pemeriksaan dalam sidang pengadilan agar berjalan dengan tertib dam lancar. Dalam hal ini hakim berwenang antara lain menetapkan hari persidangan, memerintahkan pemanggilan kepada para pihak, memerintahkan pengajuan alat-alat bukti, memberikan nasehat, mengupayakan perdamaian, menunjukkan upaya hukum dan sebagainya.

\section{Asas persidangan terbuka}

Asas ini diatur dalam Pasal 17 ayat (1) UU No. 14 Tahun 1970, yang menyatakan bahwa sidang pemeriksaan pengadilan adalah terbuka untuk umum, kecuali apabila undangundang menentukan lain. Hal ini berarti bahwa setiap orang boleh hadir, mendengar dan menyaksikan jalannya pemeriksaan perkara di pengadilan. Asas ini bertujuan untuk menjamin pelaksanaan yang tidak memihak dan adil, serta untuk melindungi HAM di peradilan. Asas ini membuka social control dari masyarakat, yaitu dengan meletakkan peradilan di bawah pengawasan umum..$^{15}$

\section{Asas kesamaann (audi et alteram partem)}

Dalam proses peradilan, kedua belah pihak harus diperlakukan secara adil dan diberi kesempatan yang sama dalam membela kepentingan masing-masing. Asas ini menghendaki adanya keseimbangan prosessuil dalam pemeriksaan. Oleh karena itu hakim tidak boleh hanya mendengar keterangan dari salah satu pihak, tanpa memberi kesempatan pihak lain untuk menyampaikan pendapatnya.

6. Asas putusan disertai alasan-alasan (motievering plicht)

Pasal 23 UU No. 14 tahun 1970 menegaskan bahwa semua semua putusan pengadilan harus disertai alasan-alasan yang dijadikan dasar mengadili. Oleh karena itu menjadi kewajiban hakim untuk memberikan pertimbangan yang cukup pada putusan yang dijatuhkan. ${ }^{16}$

\section{Asas tidak ada keharusan mewakilkan}

Asas ini menyatakan bahwa pemeriksaan perkara dapat dilakukan secara langsung terhadap pihak-pihak yang berperkara, dan tidak ada keharusan dalam berperkara diwakilkan kepada ahli hukum atau pengacaranya.

8. Asas point d'interet, point d'action

Pada asasnya setiap orang dapat mengajukan gugatan perdata ke Pengadilan Negeri, tetapi dalam kenyataannya ada persyaratannya, yaitu hanya mereka yang mempunyai kepentingan yang cukup dan layak serta mempunyai dasar hukum yang berhak mengajukan tuntutan hak (gugatan) kepada pengadilan yang berwenang. Kalau selama ini hal itu hanya merupakan asas yang dikenal dalam Jiteratur, yaitu asas point d'interet, point d'action, maka akan lebih tepat kalau sekiranya asas itu dituangkan dalam peraturan hukum acara perdata yang baru.

${ }^{15} /$ bid. HIm. 17.

${ }^{16}$ Setiawan. 1992. Aneka Masalah Hukum dan Hukum Acara Perdata. Bandung: Alumni. Hlm. 358. 
9. Asas peradilan yang sederhana, cepat, dan biaya ringan

Meskipun asas ini sudah tertuang di dalam Pasal 4 ayat (2) UU No. 14 Tahun 1970, namun selama ini asas ini belum dapat sepenuhnya dimplementasikan dalam praktek, di samping karena memang tidak jelas tentang tolok ukurnya. Oleh karena itu, tidak mengherankan dalam praktek peradilan masih dijumpai banyaknya formalitas dalam beracara, pemeriksaan perkara yang lama dan berteletele, serta biaya perkara yang relatif cukup mahal. Oleh karena itu, dalam peraturan hukum acara perdata baru perlu dibuat tolok ukur yang jelas bagaimanakah ukuran sederhana, cepat dan biaya ringan. SEMA No. 6 Tahun 1992 yang memberi batas tenggang waktu penyelesaian perkara paling lama 6 bulan, kiranya perlu dipertimbangkan untuk dimasukkan dalam peraturan hukum yang baru.

Dalam penyusunan perundang-undangan hukum acara perdata yang baru perlu diatur mengenai prinsip atau asas-asas yang berlaku di dalamnya, yang merupakan penegasan kembali materi hukum acara perdata yang telah ada maupun materi baru yang sesuai dengan kesadaran dan kebutuhan hukum yang berkembang dalam masyarakat dan bangsa Indonesia.

\section{Pembaharuan Yuridis (Normatif)}

Pembaharuan hukum acara perdata sangat penting ditinjau dari segi muatan yuridis normatifnya, agar ṇantinya dapat dirumuskan norma-norma atau kaidah hukum yang responsif dan visioner. Apalagi Indonesia sebagai bekas daerah jajahan secara objektif tidak dapat menghindari adanya pengaruh hukum dari pemerintah Hindia Belanda yang berwatak Eropa Kontinental. Meskipun setelah merdeka, dengan politik hukum yang dianutnya, bangsa Indonesia bertekad untuk melakukan pembaharuan hukum (law reform). Kemudian yang terjadi adalah pembaharuan hukum secara mutatis mutandis. Akhirnya ditambah dengan faktor heterogenitas masyarakat, maka situasi hukum yang pluralistik sering tidak dapat dihindari. Bahkan dalam era globalisasi saat ini, pengaruh hukum sistem Anglo Saxon juga tidak dapat dihindarkan, terutama pengaruh dari Amerika Serikat. Apalagi fenomena dunia tanpa batas dan cyber law menuntut tersedianya instrumen hukum yang responsif, untuk mengantisipasi berbagai permasalahan yang akan menyertainya.

Dalam rangka penataan kembali materi hukum acara perdata yang tersebar dalam berbagai peraturan perundang-undangan, dalam RUU Hukum Acara Perdata perlu diatur tentang materi-materi yang merupakan penegasan kembali dari materi yang sudah ada seperti tuntutan hak, wewenang pengadilan untuk mengadili, kewajiban mengundurkan diri, hak ingkar, upaya menjamin hak, pemeriksaan sidang pengadilan negeri, kesaksian, putusan dan upaya hukum terhadap putusan. Di samping itu diatur pula materi baru, antara lain upaya hukum luar biasa yang disebut dengan peninjauan kembali, lembaga prorograsi, pembuktian, permohonan kasasi, yang hanya dapat diajukan . oleh kuasa dari pihak-pihak yang berperkara dengan kuasa khusus, diaturnya kembali lembaga pengadilan dan pelaksanaan putusan arbitrase. ${ }^{17}$

17Penjelasan Umum RUU Hukum Acara Perdata bagian alinea terakhir. 
Apabila dicermati dalam RUU Hukum Acara Perdata yang baru, sebagian besar materinya merupakan penggabungan dari beberapa peraturan perundang-undangan hukum acara perdata yang ada, seperti HIR, Rbg, Rv, dan UU No. 14 Tahun 1985. Meskipun demikian harus diakui dalam beberapa hal memang sudah ada kemajuan atau perubahan dibandingkan dengan peraturan hukum acara perdata positif sekarang ini. Beberapa kemajuan atau perubahan penting yang diatur dalam RUU Hukum Acara Perdata dibandingkan hukum acara perdata positif, di antaranya sebagai berikut:

1. Pemanggilan kepada para pihak menurut Pasal 17 RUU Hukum Acara Perdata dapat melalui pengumuman di surat kabar.

2. Pasal 29 RUU Hukum Acara Perdata mengatur kewenangan Pengadilan Tinggi dalam memeriksa perkara prorograsi.

3. Pasal 54 RUU Hukum Acara Perdata mengatur tentang sita pesawat udara

4. Pasal 63 RUU Hukum Acara Perdata menyatakan bahwa hakim wajib mengupayakan perdamaian terhadap pihak-pihak yang berperkara, dan upaya perdamaian:tersebut dapat dilakukan setiap saat sampai sebelum perkara diputuskan, dan apabila kewajiban tersebut tidak dilaksanakan mengakibatkan putusan batal demi hukum.

5. Pasal 77-84 RUU Hukum Acara Perdata mengatur pemeriksaan dengan acara singkat, yaitu sidang pengadilan dengan hakim tunggal untuk memeriksa dan memutus dengan acara singkat yang menurut sifat sengketanya memerlukan pemeriksaan dan putusan dengan segera. Misalnya sengketa tentang penyegelan barang atau pembukaan penyegelan barang-barang.

6. Pasal 87 RUU Hukum Acara Perdata menyebutkan adanya bukti memaksa, yaitu yang mewajibkan hakim untuk membenarkan sisi alat bukti tersebut atau mengakui kekuatan pembuktian yang diberikan oleh undang-undang terhadap alat-alat bukti tersebut. Misalnya akta otentik memberikan pembuktian yang bersifat memaksa terhadap setiap orang mengenai apa yang disaksikan dan diperbuat oleh pejabat umum dalam lingkup kewenangannya.

7. Pasal 109 RUU Hukum Acara Perdata menyebutkan bahwa pihak berperkara dapat juga didengar sebagai saksi.

8. Pasal 110 ayat (2) RUU Hukum Acara Perdata menyatakan bahwa tiada seorangpun dapat dipaksa untuk dapat menghadap Pengadilan Negeri untuk memberi kesaksian jika yang bersangkutan bertempat di luar wilayah hukum Pengadilan Negeri yang memeriksa perkara.

9. Pasal 151 ayat (4) RUU Hukum Acara Perdata menyatakan bahwa jumlah biaya perkara ditetapkan berdasarkan peraturan biaya perkara yang ditetapkan dengan Keputusan Menteri

10. Pasal 155 RUU Hukum Acara Perdata memberikan batasan nilai perkara yang dapat diajukan banding adalah perkara perdata yang pokok gugatannya bernilai 1 (satu) juta rupiah atau lebih.

11. Pasal 159 ayat (3) RUU Hukum Acara Perdata menyebutkan bahwa pemohon banding diharuskan mengajukan memori banding kepada panitera Pengadilan Negeri selambat-lambatnya dalam waktu satu bulan setelah mendapatkan kesempatan 
$\therefore$ untuk mempelajari berkas perkara.

12. Pasal 167 RUU Hukum: Acara" Perdata $\therefore$ menyebutkan adanya lembaga permohonan $\therefore \therefore$ :kasasi demi kepentingan hukum oleh - Jaksa Agung karena jabatannya yang diperiksa dan diputus oleh Pengadilan Tingkat Pertama atau Pengadilan Tingkat Banding.

13. Pasal 198 RUU. Hukum Acara Perdata menyebutkan bahwa. barang milik negara tidak, dapat disita.

14. Pasal 223 RUU, Hukum Acara Perdata menyebutkan adanya lembaga'prorograsi, yaitu gugatan dapat diajukan langsung kepada. Ketua Pengadilan Tinggi yang berwenang memeriksa perkara tersebut dalam tingkat banduing sebagai peradilan tingkat pertama, jika para. pihak yang

- berperkara telah setuju untuk itu yang

$\because$ dituangkan dalam akta.

15. Pasal 266 RUU Hukum. Acara Perdata menyebutkan bahwa pada saat.undangundang initmulai.berlaku,-maka. HIR, UU No. Tahun 1947; $1 \mathrm{RBg}$, UU No, $* 1$ Drt. Tahun. 1951,, UU, No, 14 Tahun:1985 sepanjang "mengenai zasasi dan

$\because$ - peninjauan kembali perkara perdata, ni. ketentuan iyang: diatur dalam peraturan perundang-undangan lain sepanjang ... mengenai i hukum u'ācara .perdata;

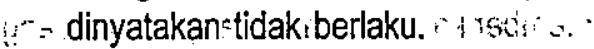

15 Lébih lanjut kalau dicermati,' di' samping dalam RUU Hukum Acara Perdata yang baru sudah ada "béberapa perubahan dan Kemajúan, tetapi Rư Hukum Acara Perdata belum ' sepenuhnya "merespon atau mengakomodir perkembangan hukum yang terjadi, terutama dengan muncúlnya lembagalembaga' baru yang berasal dari pengaruh sistem hukum Anglo Saxon atau karena pesathya perkembangan teknologi informasi. Misalnya upaya gugatan class action yang berasal dari sistem hukum anglo saxon, meskipun sampai sekarang ini sudah seringkali diajukan ke pengadilan, tetapi masih sering mengahadapi kendala karena belum diaturnya prosedur beracara class action dalam hukum acara perdata positif. Demikian pula banyaknya transaksi bisnis melalui sistem electronic record dan digital signature, kalau kemudian terjadi sengketa menghadapi kendala dalam proses pëmbuktiannya, karena alat bukti yang dikenal hukum acara perdata dalam konteks ini berupa alat bukti 'tertulis (surat). Oleh karena itu sudah selayaknya perkëmbangan-perkembangan baru seperti itu. harus direspon dan dituangkan dalam peraturán perundang-undangản hukum àcara perdatä yang baru nantinya.

\section{Pembaharuan Sosiologis}

se:Pembaharuan muatan sosiologis diperlukan karena' 'masyarakatlah,yang 'pada' akhirnya akan diposisikan sebagai pihak user (pengguna), oleh ,karena itu suatu peraturan :perundangundangan, harus'mendapatkan' legitimasi dari masyarakat, supaya keberlakuanya dapat diterima oleh masyarakàt.' Sehubungan dengan itu ada dua teori yang 'dikenal, yaitu teori: pengakuan dan teori kekuasaan. Kedua teori itu,; -sebagaimanas digunakan oleh Soerjono Soekanto ${ }^{18}$.dalam menilai keberlakuan

$\because{ }^{118}$ Soérjono Soekanto: 1979: "Masalah Kedudukan dan Peranän Hukum Ádat." Jakarìa: Academika. sebagaimana dikutip oleh Hanafi.."Reformàsi Sistem Pertanggungjawaban Pidana." Jurnal Hukum No. 11 Volume 6:Tahun 1999:- 
hukum adat - di - Indonésia, juga akan dipergünakan dalam menilai sejauh mana sejauth mana peráturan perundang-undangan

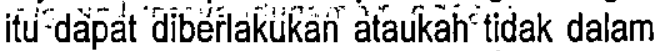
masyarakat.

1 Menúrùt pandangan teori pertama, yakni teơri pengakuan, berlaku tidaknya suatu norma hưkum itu ditentukan oleh sejaù mana másyarakat menerima dan mengakui sebagai norma yang ditaati. Sedangkan menurut teori kedùa, yakni teori kekuasaan, berlaku tidaknya suatú norma itu dilihat sejaù mana norma itu dibèrlakukukan oleh suatu kekuasaan tertentu. Sécara ekstrem dapat dikatakan bahwa dalam pandangan terakhir, suatu norma' hukum itu berlaku karena kekuatannya sendiri, yang bersifat imperatit (perintah), terlepas dari pértimbangan adà tidaknyà pengakuan -dari másyarakat yang diaturnya.

Dälam pandangan teori pengakuan masyarakat, berlakunya suatu norma hukum apabila norma itu diterima dan diakui oleh wárga masyarakat yang diaturnya. Bahkan secara ekstrem, menurut pandangan teori ini, suatu ketentaun hukum baru boleh dianggap sebagai:hukum; apabila-ia diakui secara sah oleh masyarakatnya sendiri. ${ }^{19}$..

Hukum acara perdata positif yang

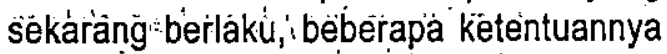
terkadang masih menimbuilkan mašalah atau menjadi bahan perdebatan para ahli hukum, karena dianggáp tidak lagi sesuai dengan semangat pembaharuan hukum. Misalnya selama ini kebenaran yang hendak dicari hakim dalam perkara perdata lebih cenderung kepada kebenaran formil, yaitu kebenaran yang didasarkan pada keterangan dan buktibukti formil di persidangan, tanpa mensyaratkan adanya keyakinan hákim. Oleh karena itu, dalam perkara perdata ada alatalat bukti yang bersifat memaksa (dwingende bewijskracht), yang mengikat hakim dalam melakukan penilaian terhadap alat-alat bukti tersebut. Dengan demikian kalau dalam persidangan, diajukan alat-alat bukti seperti akta otentik, pengakuan, sumpah decisoir maka dalil-dalil yang diajukan oleh pihak yang bersangkutan dianggap sebagai suatu peristiwa yang kongkrit atau benar-benar terjadi. Hal ini merupakan konsekwensi logis dari kebenaran formil, bahwa kenyataankenyataan yang terjadi dalam persidangan tidak selalu mencerminkan kenyataankenyataan sesungguhnya di lapangan. Pihak yang dikalahkan dalam putusan pengadilan, belum tentu sebagai pihak yang sesungguhnya bersalah, tetapi bisa saja karena tidak dapat membuktikan peristiwa yang dikemukakannya. $\mathrm{Hal}$ ini berbeda dengan dengan kebenaran yang hendak dicari dalam perkara pidana dan perkara administrasi negara, yang berupaya menemukan kebenaran materiel, artinya di samping didasarkan pada bukti-bukti yang ada juga mensyaratkan adanya keyakinan hakim. Dalam sistem pembuktian perkara pidana dan administrasi negara, tidak mungkin hakim menjatuhkan putusan hanya didasarkan pada bukti-bukti formil di persidangan saja, tanpa adanya keyakinan hakim itu sendiri. Dengan demikian dalam perkara pidana dan

${ }^{19}$ Ibid. 
administrași negara, kontrol hakim lebih besar melalui keyakinannya. ${ }^{20}$

Mengingat dalam hukum acara perdata positif maupun dalam RUU Hukum Acara Perdata, tidak secara tegas menyebutkan sistem pembuktian yang dipergunakan, maka dapat menimbulkan interpretasi yang beragam bagi para hakim maupun penegak hukum lainnya. Untuk itu dalam perundang-undangan hukum acara perdata yang baru perlu diatur dan dirumuskan lebih jelas. Penegasan sistem pembuktian ini penting, karena akan menentukan kebenaran mana yang harus dicari oleh hakim. ${ }^{21}$

\section{Aspek-aspek Kebijakan Pembaharuan Hukum Acara Perdata}

Kebijakan pembaháruan hukum, termasuk di dalamnya pembaharuan hukum acara perdata, agar dapat memenuhi kualifikasi perundang-undangan yang ideal, perlu memperhatikan empat aspek, yaitu aspek politik hukum, asas-asas pembentukan peraturan perundang-undangan yang patut, teknik penyusunan peraturan perundangundangan, serta memenuhi syarat kekuatan berlakunya.

Pertama, aspek politik hukum. Politik hukum merupakan kebijakan negara melalui badan-badan yang berwenang untuk menetapkan peraturan-peraturan yang dikehendaki yang diperkirakan bisa digunakan untuk mengekspresikan apa yang terkandung dalam masyarakat dan untuk mencapai apa yang dicita-citakan. Politik hukum bertujuan untuk mewujudkan peraturan-peraturan yang baik sesuai dengan keadaan dan situasi pada saat itu. ${ }^{22}$

Memahami politik hukum suatu perundang-undangan merupakan hal yang penting, mengingat pembuatan hukum atau perundang-undangan tidak dapat terlepas dari sistem politik yang ada pada waktu itu. Hukum merupakan produk politik. Hukum dipandang sebagai kristalisasi dari proses interaksi atau

${ }^{20}$ Bambang Sutiyoso. 2001. "Relevansi Kebenaran Formil' dalam Pembuktian Perkara Perdata di Pengadilan." Tesis S-2 IImu Hukum Universitas Gajah Mada. HIm. 155.

${ }^{21} /$ bid. Him. 166.

${ }^{2}$ Sudarto sebagaimana dikutip oleh Hanafi. 1998. Politik Hukum Pidana. Yogyakarta: Perpustakaan Fakultas Hukum UII. Him. 1. Istilah politik hukum menurut Sugeng: Istanto dapat diartikan sebagai act of choice in determining ius constituendum (tindakan memilih dalam upaya menentukan hukum yang dicita-citakan). Batasan tersebut dilihami oleh pendapatnya Mathews yang menyatakan bahwa politik itu intisarinya adalah act of choice. Baca tulisan Sugeng Istanto. Bahan Kuliah Politik Hukum. Program S-2 limu Hukum'UGM, 1998. Politik hukum menurut Abdul Hakim Ganida Nusantara sebagaimana dikutip oleh Moh. Mahfud22, adalah kebijaksanaan hukum (legal policy) yang hendak atau telah dilaksanakan secara nasional oleh Pemerintah Indonesia, yang dalam implementasinya meliputi: (a). Pembangunan hukum yang berintikan pembuatan hukum dan pembaharuan hukum terhadap bahan-bahan hukum yang dianggap asing atau tidak sesuai dengan kebutuhan dengan penciptaan hukum yang diperlukan, (b). Pelaksanaan ketentuan hukum yang telah ada, termasuk penegasan fungsi lembaga dan pembinaan anggota penegak hukum. Lihat tulisan Moh. Mahfud. "Intervensi Politik terhadap Hukum di Indonesia. disampaikan pada Forum Bedah Buku "Politik Hukum di Indonesia"pada tanggal 15 Oktober 1998 dị Hotel Santika Yogyakarta. 
pergulatan dari kehendak-kehendak kekuatan politik yang ada. Secara das sollen politiklah yang harus tunduk pada ketentuan hukum, tetapi secara das sein (empirik) seringkali hukumlah yang sebenarnya diintervensi oleh politik, sehingga karakter produk hukum dan penegakannya akan sangat ditentukan oleh konfigurasi politik yang melatarbelakanginya. Konfigurasi politik tertentu akan melahirkan karakter produk hukum tertentu dengan spesifikasi sebagai berikut: (a). Konfigurasi politik demokratis akan melahirkan hukumhukum yang berkarakter responsif atau populistis, (b). Konfigurasi politik otoriter akan melahirkan hukum-hukum yang berkarakter ortodoks/konservatif. ${ }^{23}$ Dengan memperhatikan adanya politik hukum, diharapkan pula dapat mengantisipasi dan mensikapi secara adil terhadap kemungkinan tindakan kesewenangan penguasa terhadap rakyat.

Kedua, dalam rangka pembaharuan dan penyusunan hukum, perlu juga diperhatikan tentang asas-asas pembentukan peraturan perundang-undangan yang patut. Asas-asas tersebut merupakan dasar-dasar umum dari pembentukan norma-norma dalam peraturan perundang-undangan. Van der Vlies sebagaimana dikutip oleh Maria Farida Indrati, membagi asas-asas dalam pembentukan peraturan-peraturan yang patut (beginsellen van behorlijke regelgeving) ke dalam asasasas yang formal dan material. Asas-asas yang formal meliputi: (a) asas tujuan yang jelas (beginsel van duidelijke doelstelling), ; (b) asas organ/lembaga yang tepat (beginsel van het juiste orgaan); (c) asas perlunya pengaturan (het noodzakelijkheids beginsel); (d) asas dapat dilaksanakan (het beginsel van uitvoerbaarheid); (e) asas konsensus (het beginsel van consensus). Sedangkan asasasas yang material meliputi: (a) asas terminologi dan sistematika yang benar (het beginsel van duidelijke terminologie en duidelijke systematiek) ; (b) asas dapat dikenali (het beginsel van de kenbaarheid); (c) asas perlakuan yang sama dalam hukum (het rechtsgelijkheidsbeginsel) ; (d) asas kepastian hukum (het rechtszekerheids beginsel); (e) asas pelaksanaan hukum sesuai dengan keadaan individual (het beginsel van de individuele rechtsbedeling). ${ }^{24}$

Selanjutnya Hamid S. Attamimi berpendapat bahwa asas-asas pembentukan peraturan perundang-undangan Indonesia yang patut, secara berurutan dapat disusun sebagai berikut : (a) asas sesuai cita hukum Indonesia dan norma fundamental negara, yang tidak lain Pancasila, yang berlaku sebagai "bintang pemandu" ; (b) asas sesuai. dengan hukum dasar negara ; (c) asas sesuai dengan prinsip-prinsip negara berdasarkan atas hukum ; (d) asas sesuai dengan prinsip-prinsip pemerintahan berdasar sistem konstitusi. ${ }^{25}$ Dengan mengacu pada asas-asas pembentukan peraturan perundangundangan Indonesia yang patut tersèbut, diharapkan dapat terciptanya peraturan perundang-undangan yang baik dan dapat

\section{${ }^{23} \mathrm{lbid}$.}

${ }^{24}$ I.C. Van der Vlies. 1984. "Het wetsbegrip en beginsellen van behorlijke regelgeving," 's-Gravenhage. Vuga. HIm. 186 sebagaimana dikutip oleh Maria Farida Indrati Soepraptó. Op. Cit. HIm. 196-197.

${ }^{25} \mathrm{Hamid}$ S. Attamimi sebagaimana dikutip oleh Ibid. HIm. 198. 
mencapai tujuan secara optimal dalam pembangunan hukum di Negara Republik indonesia. ${ }^{26}$

Di dalam praktek penyelenggaraan peradilan, adanya peraturan perundangundangan yang baik akan banyak berperan dalam menunjang proses penyelengaraan peradilan dan penegakkan hukum pada umumnya, sehingga akan lebih memungkinkan tercapainya tujuan-tujuan peradilan yang diinginkan. Sedangkan untuk membuat suatu peraturan perundangundangan yang baik, diperlukan adanya persiapan-persiapan yang matang dan mendalam, antara lain pengetahuan mengenai materi muatan yang akan diatur dalam perundang-undangan, dan pengetahuan tentang bagaimana menuangkan materi muatan tersebut di dalam suatu peraturan perundang-undangan secara singkat tetapi jelas, dengan suatu bahasa yang baik dan mudah dipahami, disusun secara sistematis, tanpa meninggalkan tatacara yang sesuai dengan kaidah bahasa Indonesia dalam penyusunan kalimat-kalimatnya. ${ }^{27}$

Ketiga, menurut Sudikno Mertokusumo, bahwa dalam penyusunan suatu undangundang, terutama undang-undang hukum acara perdata yang perlu mendapat perhatian adalah dari segi teknik perundang-undangan (wetgevingstechniek). Bahwa untuk lebih menjamin kepastian hukum, peraturan hukum acara perdata tidak boleh bersifat terlalu umum. Sebaliknya dalam merumuskan undang-undang mengenai' hukum materiil akan lebih baik kalau rumusannya bersifat umum, sehingga memungkinkan penafsiran bagi hakim. Dengan demikian peraturan hukum materiil yang bersifat umum akan menjangkau kurun waktu yang panjang. Bagi peraturan hukum acara perdata, sebagai aturan permainan hakim, untuk menjamin kepastian hukum, maka kiranya lebih tepat kalau hakim tidak diberi kesempatan banyak untuk menafsirkan. Oleh karena itu rumusan peraturan hukum acara perdata tidak boleh terlalu umum. ${ }^{28}$

Keempat, tentang syarat kekuatan berlakunya peraturan hukum. Suatu peraturan hukum mempunyai beberapa persyaratan untuk dapat diberlakukan. Dalam hal ini, Sudikno Mertokusumo, mengemukakan adanya tiga persyaratan, yaitu kekuatan berlaku filosofis (filosofische Geltung), kekuatan berlaku yuridis (juridische Geltung) dan kekuatan berlaku sosilogis (soziologische Geltung). Peraturan Hukum mempunyai kekuatan berlaku filosofis apabila kaedah hukum tersebut sesuai dengan cita-cita hukum (rechtidee) sebagai nilai positif yang tertinggi (uberpositiven Werte), dalam hal ini Pancasila. Sedangkan agar peraturan hukum mempunyai

${ }^{26} /$ bid.

${ }^{27}$ Maria Farida Indrati Suprapto. 1998. Ilmu Perundang-undangan Dasar-dasar dan Pembentukannya. Yogyakarta: Kanisius. HIm. 134.

${ }^{28}$ Dikemukakan oleh Sudikno Mertokusumo dalam simposium Hukum Acara Perdata tahun $1987 \mathrm{di}$ Yogyakarta sebagaimana dikutip oleh Krisna Harahap. 1996. Hukum Acara Perdata Teori dan Praktek. Bandung: Grafiti Budi Utami. Hlm. 110. 
kekuatan berlaku yuridis, apabila persyaratan formal terbentuknya undang-undang itu telah terpenuhi. Selanjutnya kekuatan berlaku sosiologis, intinya terletak pada efektivitas atau hasil guna kaedàh hukum di dalam kehidupan bersama. Dalam hal ini berlakunya atau diterimanya hukum di dalam masyarakat itu lepas dari kenyataan apakah peraturan hukum itu terbentuk menurut persyaratan formal atau tidak. Jadi di sini berlakunya hukum merupakan kenyataan dalam masyarakat. Suatu peraturan hukum agar berlaku dan berfungsi, maka harus memenuhi ketiga persyaratan tersebut. ${ }^{29}$

Aspek-aspek yang dikemukakan di atas dalam rangka pembaharuan hukum, memang merupakan sesuatu yang ideal. Meskipun demikian, dalam upaya menyusun dan merumuskan peraturan hukum baru, sedapat mungkin rambu-rambu tersebut dipenuhi, agar produk peraturan yang dihasilkan juga memenuhi standar kualifikasi peraturan yang ideal. Sehingga diharapkan peraturan hukum tersebut bersifat aplicable dan survival, yaitu dapat bertahan dalam kurun waktu yang relatif lama. Dalam konteks ini, pembaharuan hukum acara perdata sudah selayaknya untuk mengindahkan beberapa.aspek yang telah diuraikan tersebut.

Di samping itu, diperlukan pula respon kreatif para pakar dan pelaku penegak hukum dalam memakna-artikan hukum dalam dinamika kehidupan masyarakat pada era globalisasi dewasa ini, baik dalam skala nasional maupun dalam kerangka bermasyarakat global. Adanya peran kreatif dan inovatif para pakar dan praktisi hukum, di samping dapat memberi kontribusi keadilan, juga memberikan dampak positif dalam pembaharuan hukum, yaitu jika keajegan tersebut sampai merupakan yurisprudensi, merupakan salah satu sumber hukum formal, di samping undang-undang, kebiasaan dan perjanjian sebagaimana dikemukakan oleh M.E. Algra. ${ }^{30}$ Selain itu juga sumber hukum materiil sebagai faktor-faktor masyarakat yang mempengaruhi pembentukan hukum (pengaruh terhadap undang-undang, pengaruh terhadap putusan hakim dan sebagainya). Apa yang dikemukakan oleh M.E. Algra tersebut adalah pilihan dalam upaya mengadakan pemberdayaan, aktualisasi peran, dan perubahan hukum.

\section{Simpulan}

Pembaharuan hukum acara perdàta di Indonesia merupakan conditio sine qua non dalam upaya upaya menciptakan kepastian hukum dan rasa keadilan. Terlebih peraturan hukum acara perdata positif sekarang ini merupakan produk hiukum peninggalan pemerintahan Hindia Belanda yang relatif sudah ketinggalan zaman, sehingga kurang memiliki relevansi sosial dengan situasi dan kondisi sosial yang diaturnya. Hukum acara perdata positif yang berlaku sebagai aturan main prosedural dalam beracara perdata di pengadilan, sebagian ketentuannya ternyata sudah tidak sesuai lagi dengan kesadaran dan

${ }^{29}$ Sudikno Mertokusumo. 1990. Mengenal Hukum (Suatu Pengantar). Yogyakarta: Liberty. HIm. 74-76.

${ }^{30}$ M.E. Algra, et. al. 1983. "Mula Hukum." Jakarta: Binacipta. HIm. 16. sebagaimana dikutip oleh Artidjo Alkostar. Loc. Cit. 
kebutuhan hukum yang berkembang dalam masyarakat. Oleh karena hukum acara perdata sekarang ini perlu dikaji ulang dan diperbaharui dengan konsep hukum acara perdata baru yang visioner dan responsif, baik dalam tinjauan filosofis, yuridis maupun sosiologis. Demikian pula terhadap RUU Hukum Acara Perdata meskipun sudah ada kemajuan dan perubahan dibandingkan hukum acara perdata positif, tetapi beberapa ketentuan di dalamnya perlu disempurnakan kembali dengan mengundang para ahli hukum dan praktisi hukum, sehingga masalah-masalah perkembangan hukum terutama yang bersifat kekinian (aktual) mendapatkan wadah sebagaimana mestinya.

\section{Daftar Pustaka}

Alkostar, Artidjo. "Reformasi Hukum Pidana Politik." Jurnal Hukum No. 11 Volume 6. Tahun 1999.

Basah, Sjachran. 1989. Hukum Acara Pengadilan Dalam Lingkungan Peradilan Administrasi (HAPLA). Jakarta: Rajawali Pers.

Hanafi. "Reformasi Sistem Pertanggungjawaban Pidana." Jurnal Hukum No. 11 Volume 6 Tahun 1999.

1998. Politik Hukum Pidana. Yogyakarta: Perpustakaan Fakultas Hukum UII.

Harahap, Krisna. 1996. Hukum Acara Perdata Teori dan Praktek. Bandung: Grafiti Budi Utami.

Harahap, Zairin. 2001. Hukum Acara Peradilan Tata Usaha Negara. Jakarta: RajaGrafindo Persada.
Istanto, Sugeng . Bahan Kuliah Politik Hukum. Program S-2 IImu Hukum UGM, 1998

Luthan, Salman. "Kebijakan Kriminalisasi dalam Reformasi Hukum Pidana." Jurnal Hukum No.11 Volume 6.1999.

Mahfud, Moh.. "Intervensi Politik terhadap Hukum di Indonesia. Disampaikan pada Forum Bedah Buku "Politik Hukum di Indonesia" pada tanggal 15 Oktober 1998 di Hotel Santika Yogyakarta.

Mertokusumo, Sudikno. 1990. Mengenal Hukum (Suatu Pengantar). Yogyakarta: Liberty.

1998. Hukum Acara Perdata Indonesia. Yogyakarta: Liberty.

Muhammad, Abdul Kadir. 1992. Hukum Acara Perdatá Indonesia. Bandung: Citra Aditya Bakti.

Rubini dan Chidir Ali. 1974. Pengantar Hukum Acara Perdata. Bandung: Alumni.

Setiawan. 1992. Aneka Masalah Hukum dan Hukum Acara Perdata. Bandung: Alumni.

Subekti. 1975. Hukum Pembuktian. Jakarta: Pradnya Paramita.

1989. Hukum Acara Perdata. BPHN Departemen Kehakiman. Bandung: Bina Cipta.

Suprapto, Maria Farida Indrati. 1998. IImu Perundang-undangan Dasar-dasar dan Pembentukannya. Yogyakarta: Kanisius. 
Sutiyoso, Bambang. 2001. "Relevansi Kebenaran Formil dalam Pembuktian Perkara Perdata di Pengadilan." Tesis

S-2 IImu Hukum Universitas Gajah Mada.
Syahrani, Riduan. 2000. 'Buku Materi Dasar hukum Acara Perdata. Bandung: Citra Aditya Bakti.

(๑) (2) 